\title{
The earliest known occurrence of Elgaria (Squamata: Anguidae) and a minimum age for crown Gerrhonotinae: Fossils from the Split Rock Formation, Wyoming, USA
}

\author{
Simon Scarpetta
}

\begin{abstract}
Gerrhonotinae is a clade of ecologically diverse anguid lizards with a relatively rich Cenozoic fossil record. The clade was well-studied by biologists researching molecular phylogenetics of extant lizards, but there is a paucity of reliable fossil data with which to analyze the diversification and historical biogeography of the group. Although several Cenozoic lizard fossils were attributed to Gerrhonotinae, most specimens were identified on the basis of overall morphological similarity to extant taxa. Here, I use an apomorphy-based approach to identify and describe the earliest known fossil referable to the extant gerrhonotine genus Elgaria and provide a minimum divergence time between stem Elgaria and other gerrhonotines. The fossil and associated fossil material were found in the Split Rock Formation in the Granite Mountains of central Wyoming. The minimum chronostratigraphic age of Elgaria is $16.7 \mathrm{Ma}$. Additionally, the geographic range of Elgaria is extended several hundred miles from the closest extant occurrence of the genus.
\end{abstract}

Simon Scarpetta. Jackson School of Geological Sciences, The University of Texas at Austin, 23 San Jacinto Boulevard and East 23rd Street, Austin, TX 78712-1722, USA. scas100@utexas.edu

Keywords: Anguidae, fossil, calibration, Elgaria, Miocene, paleobiogeography

Submission: 18 November 2017 Acceptance: 6 April 2018

Scarpetta, Simon. 2018. The earliest known occurrence of Elgaria (Squamata: Anguidae) and a minimum age for crown Gerrhonotinae: Fossils from the Split Rock Formation, Wyoming, USA. Palaeontologia Electronica 21.1.1FC 1-9. https://doi.org/ $10.26879 / 837$

palaeo-electronica.org/content/fc-11

Copyright: April 2018 Society of Vertebrate Paleontology.

This is an open access article distributed under the terms of the Creative Commons Attribution License, which permits unrestricted use, distribution, and reproduction in any medium, provided the origial author and source are credited.

creativecommons.org/licenses/by/4.0/

Calibrations published in the Fossil Calibration Series are accessioned into the Fossil Calibration Database

(www.fossilcalibrations.org). The Database is a dynamic tool for finding up-to-date calibrations, and calibration data will be updated and annotated as interpretations change. In contrast, the Fossil Calibration papers are a permanent published record of the information on which the calibrations were originally based. Please refer to the Database for the latest data. 


\section{INTRODUCTION}

Gerrhonotines, commonly called alligator lizards, are a clade of anguid lizards with a substantial fossil record and a diverse assemblage of extant species inhabiting regions of North and Central America. There are over 50 extant species in six genera that inhabit many ecosystems, including desert oases, temperate pine-oak forests, and tropical cloud forests (Lamar et al., 2015; Leavitt et al., 2017). Crown Gerrhonotinae is the clade composed of the last common ancestor of the genera Elgaria, Gerrhonotus, Coloptychon, Barisia, Mesaspis, and Abronia and all its descendants (see Figure 1). Gerrhonotinae has been the subject of or included in many phylogenetic analyses of molecular data (Macey et al., 1999; Conroy et al., 2005; Pyron et al., 2013; Zheng and Wiens, 2016; Leavitt et al., 2017) and of morphological data (Good, 1987; Conrad, 2008; Conrad et al., 2011; Gauthier et al., 2012), but few currently described fossils are usable for node calibrations.

Several previously described Cenozoic lizard fossils were referred to Gerrhonotinae (Gilmore, 1928; Estes, 1963; Estes and Tihen, 1964; Robin-

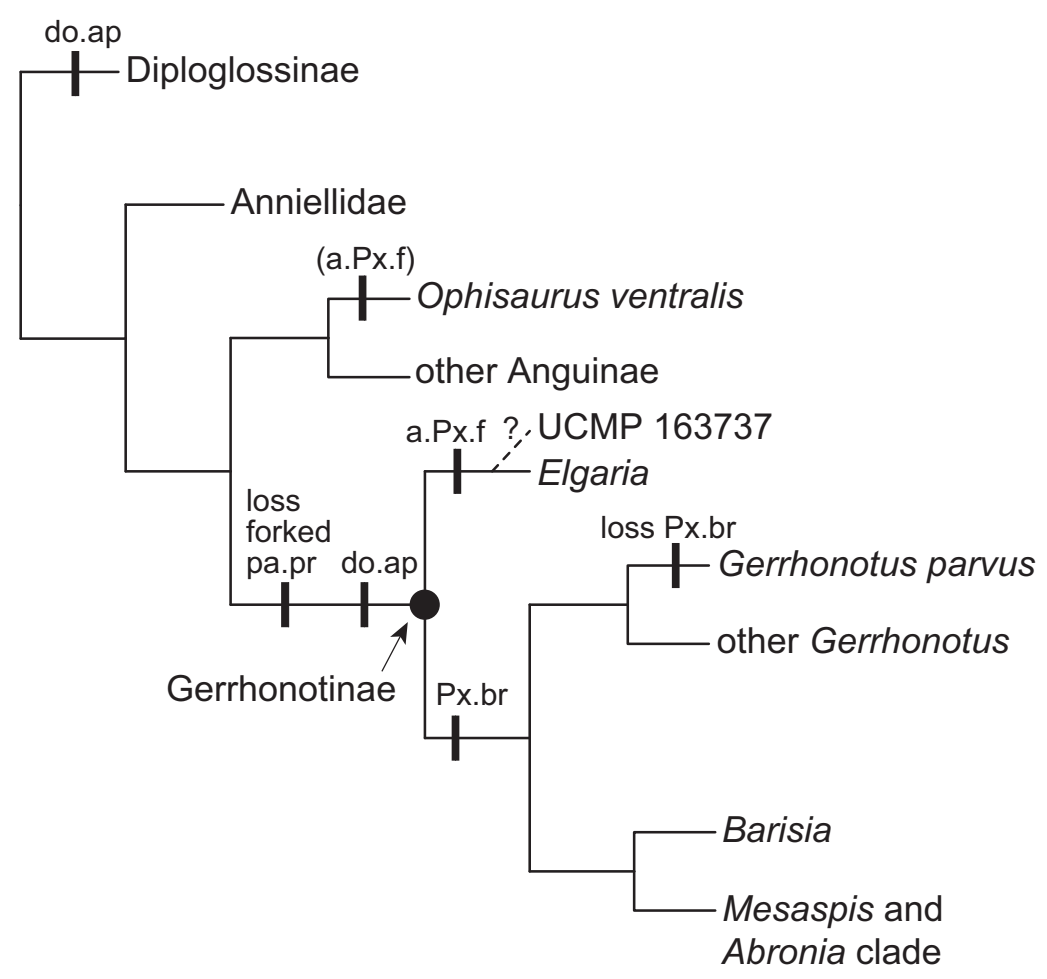
Abronia clade son and Van Devender, 1973; Holman, 1973, 1976; Gauthier, 1982; Norell, 1989). However, almost all of those fossils, including those referred to the genus Elgaria, lacked known apomorphies of Gerrhonotinae (Good, 1988). Fossils were attributed to Elgaria in faunal lists, but without any justification for their identification and without referencing specimen numbers for the fossils (Whistler and Lander, 2003; see Leavitt et al., 2017). An apomorphy-based approach was previously used to identify fossils of Gerrhonotinae (Smith, 2009), but no fossil has been referred to Elgaria using apomorphies. Fossils identified using apomorphies are necessary for node calibrations (Parham et al., 2012).

Phylogenetic analyses of molecular and morphological data produce hypotheses of squamate relationships that differ in many respects but agree in others (see Conrad, 2008; Gauthier et al., 2012; Pyron et al., 2013; Zheng et al., 2016). Although the phylogenetic interrelationships of anguimorph lizard clades differ between recent molecular (Pyron et al., 2013; Zheng and Wiens, 2016) and morphological (Bhullar, 2011; Gauthier et al., 2012) analyses, the composition and monophyly of sev-

FIGURE 1. Phylogeny of Anguidae with tree topology adapted from Zheng and Wiens (2016). Branch lengths are arbitrary. The node calibrated in text is represented by the circle labelled Gerrhonotinae. The specimen UCMP 163737 is attached to the Elgaria panstem lineage. Character state changes are labelled by black bars, and parentheses around a change indicate that the state change was not present in all specimens examined. Abbreviations: a.Px.f = anterior premaxillary foramen; do.ap = dorsal ossification of the alveolar plate; $p a . p r=$ palatal process; Px.br $=$ premaxillary bridge. 

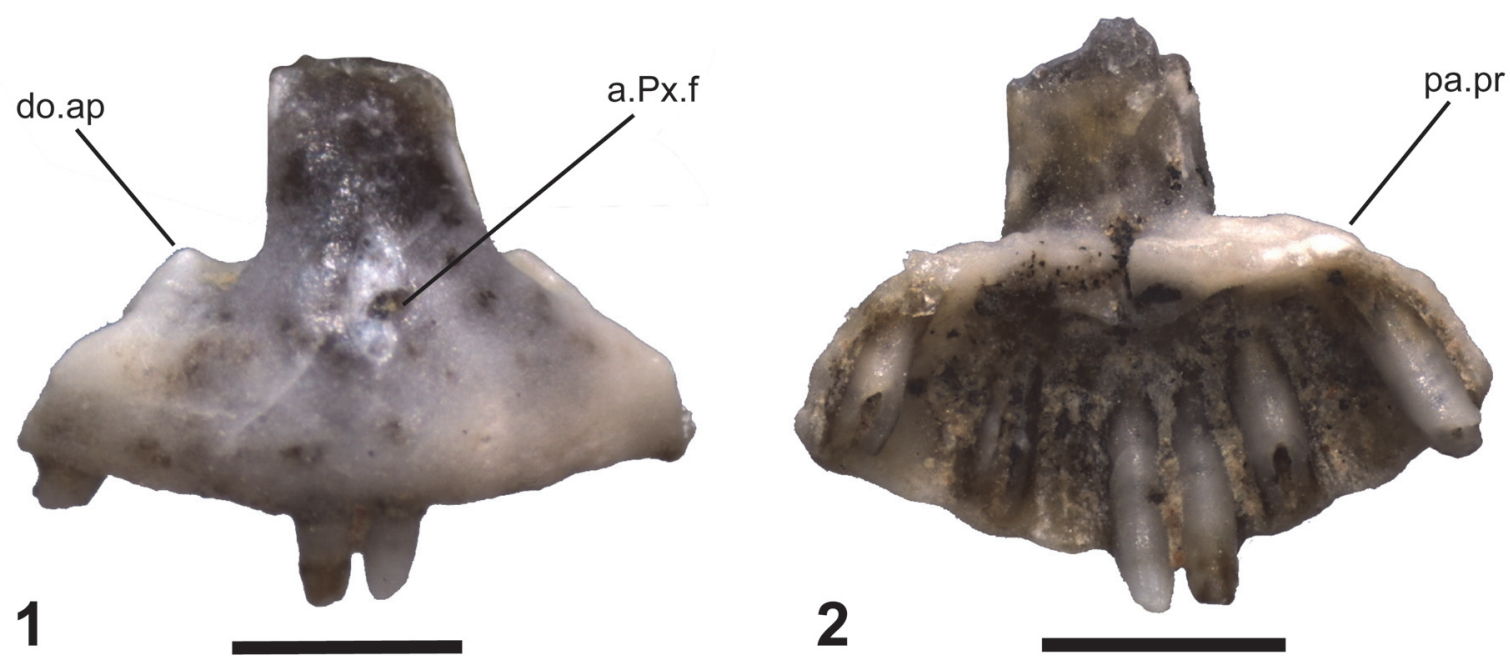

FIGURE 2. Oldest fossil of Elgaria, UCMP 163737. All scale bars equal $1 \mathrm{~mm}$. 1, UCMP 163737 in anterior view. 2 , UCMP 163737 in posterior view. Anatomical abbreviations: a.Px.f = anterior premaxillary foramen; do.ap = dorsal ossification of the alveolar plate; pa.pr = palatal process.

eral anguimorph clades (e.g., Anguidae, Gerrhonotinae, Diploslossinae, Anguinae, Xenosaurus) is consistent. Thus, many apomorphies are stable between analyses, and fossils can be placed in molecular topologies with some care and attention to which clades are congruent between topologies and which clades are not (Head, 2015). Here, I provide conclusive evidence for the first known occurrence of the gerrhonotine Elgaria. I describe a premaxilla fossil and place it phylogenetically with an apomorphy-based approach, establishing a minimum age for crown Gerrhonotinae. I also describe a dentary from the same locality that is diagnosable to Gerrhonotinae.

\section{MATERIALS}

The fossil specimens are housed in the University of California Museum of Paleontology (UCMP). The specimens (UCMP 163737 and UCMP 163012) were found in the Split Rock Formation in the Granite mountains of central Wyoming at the locality UCMP V69190. Comparative specimens are from the Texas Memorial Museum (TMM), California Academy of Sciences (CAS), and Sul Ross State University (SRSU) (see Appen$\operatorname{dix} 1)$.

\section{CALIBRATIONS}

Node calibrated. Basal divergence within crown Gerrhonotinae between stem Elgaria and other gerrhonotines.

Taxon. Elgaria sp.
Specimen. UCMP 163737.

Additional material. None.

Phylogenetic justification. The premaxilla (Figure 2) is referred to Lepidosauria by the presence of teeth that are superficially attached to the jaw and to Squamata by the presence of pleurodont dentition (Gauthier et al., 1988). An unpaired, fused premaxilla is a synapomorphy of Squamata (Gauthier et al., 2012) or of Squamata exclusive of Gekkota (Conrad, 2008). Four bilateral tooth positions (not including a midline position) are a synapomorphy of Anguidae (Conrad et al., 2011), but this state is also present in Xenosaurus (Bhullar, 2011). Xenosaurus has heavily sculptured and extensive dermal rugosities on the anterodorsal surface of the premaxilla, which are absent in UCMP 163737. Among anguids, a dorsal ossification on the alveolar plate posterior to the medial ethmoidal foramen is present in Gerrhonotinae and Diploglossinae and is absent in Anguinae. All specimens examined of the anguine genera Ophisaurus and Pseudopus do not possess this ossification. A forked palatal process is present in both Anguinae and Diploglossinae (Evans, 2008; Conrad et al., 2011), and is absent in UCMP 163737. Every specimen of Ophisaurus and Pseudopus examined here has a forked palatal process. Additionally, the anteriormost surface of the premaxilla of Ophisaurus is proportionally taller and flatter compared to that of UCMP 163737 and to all other anguids examined. Lateral flanges on the nasal process of the premaxilla are present in Diploglossinae but are absent in UCMP 163737. The specimen is 

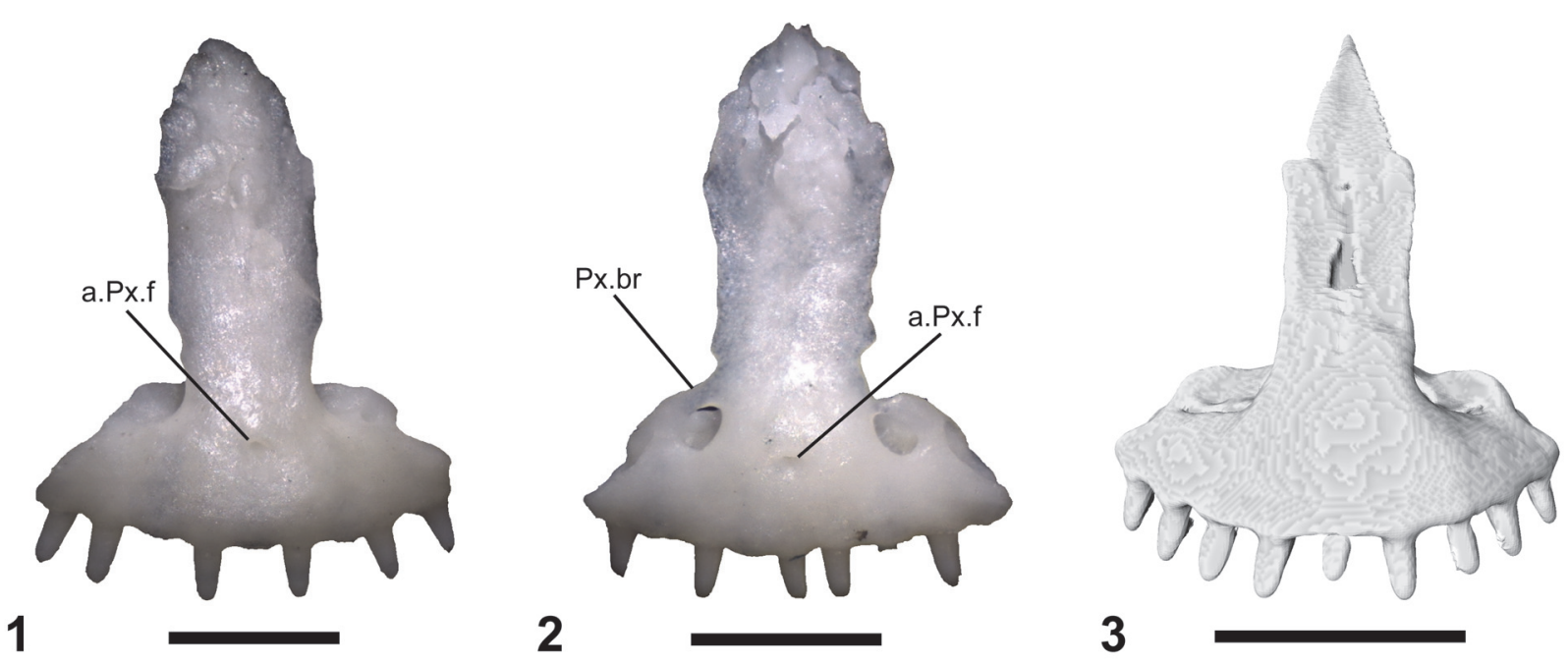

FIGURE 3. Premaxillae of extant gerrhonotines. All scale bars equal $1 \mathrm{~mm}$. All images are in anterior view. 1, Elgaria multicarinata TMM 8988. 2, Elgaria kingii TMM M-8981. 3, Gerrhonotus parvus SRSU 5358. SRSU 5358 is an alcohol-preserved specimen that was scanned at the University of Texas High-Resolution CT facility (UTCT). Anatomical abbreviations: a.Px.f = anterior premaxillary foramen; Px.br = premaxillary bridge.

assigned to Gerrhonotinae based on the presence or absence of these characters.

An ossified bridge connects or almost connects the nasal process of the premaxilla with the alveolar plate, partially or completely isolating the medial ethmoidal foramen from the external naris, in the gerrhonotine genera Gerrhonotus, Barisia, Mesaspis, and Abronia (Good, 1987). The bridge is generally absent in Elgaria (Figure 3.1), but is occasionally present in the extensively studied taxon Elgaria multicarinata (see Bhullar, 2011) and Elgaria kingii (Figure 3.2). The bridge is absent in Gerrhonotus parvus (Figure 3.3). UCMP 163737 lacks a bridge, but possesses an anterior premaxillary foramen, which is present in most Elgaria (Ledesma, personal commun., 2017) and is absent in both Gerrhonotus parvus examined (Figure 3.3). An anterior premaxillary foramen is absent in all other taxa examined besides one specimen of Ophisaurus ventralis (CAS 74296). The presence of that foramen is not plesiomorphic for Gerrhonotinae or Anguinae and is derived in Elgaria. Thus, the character combination of the presence of an anterior premaxillary foramen and the absence of an ossified bridge on the premaxilla is apomorphic of Elgaria among gerrhonotines (see Figure 1). The fossil does not have any apomorphies of the other five extant genera of gerrhonotine lizards.

However, a lack of a premaxillary bridge is plesiomorphic for Gerrhonotinae with respect to its sister taxon Anguinae (Pyron et al., 2013; Zheng and Wiens, 2016). That character is also plesiom- orphic in morphological analyses in which Gerrhonotinae and Diploglossinae are sister taxa (Gauthier et al., 2012). The presence of an anterior premaxillary foramen is derived in Elgaria with respect to most other anguids and to other gerrhonotines, but possessing this character does not definitively place the fossil within the crown of Elgaria. UCMP 163737 may fall on the stem or the crown of Elgaria regardless of which tree topology is accepted. I make no species assignment because the specimen does not possess apomorphies of any species of Elgaria. In addition, the age of the fossil likely precludes assignation to an extant (crown-clade) species. The specimen does not possess any unique morphological features sufficient to warrant naming a new taxon. Given the morphology of UCMP 163737, I assign the specimen to the Elgaria panstem.

Minimum age. 16.7 Ma.

Maximum age. Indeterminate.

Age justification. A tuff near the base of the Split Rock Formation was dated by ${ }^{40} \mathrm{Ar} / 39 \mathrm{At}$ at $17.4 \pm$ $0.08 \mathrm{Ma}$ (Izett and Obradovich, 2001), but was later corrected to $17.60 \pm 0.08 \mathrm{Ma}$ (Lander et al., 2013). UCMP V69190 occurs in normal and reversed magnetozones correlated with chrons C5Dn and C5Cr, 17.5-16.7 Ma (Hilgen et al., 2012; Lander et al., 2013). The lizard fossils were found in conjunction with a middle Hemingfordian mammal fauna, which includes the oreodontids Brachycrus vaughani and Brachycrus sweetwaterensis (Lander et al., 2013). Other researchers assigned 


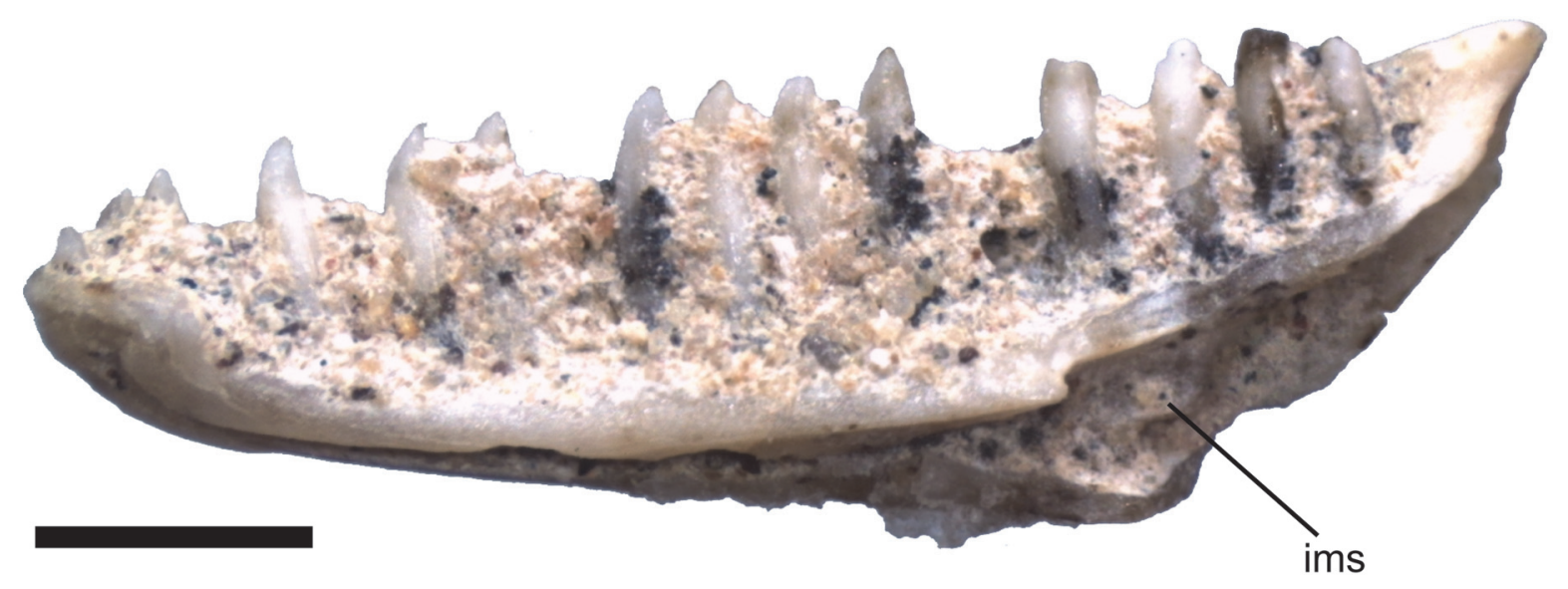

FIGURE 4. UCMP 163012 in medial view. Scale bar equals $1 \mathrm{~mm}$. Anatomical abbreviation: ims = intramandibular septum.

a chronostratigraphic age to the mammal fauna in the Split Rock Formation of approximately 17.516.7 Ma, although they considered the fauna to be late Hemingfordian in age (Tedford et al., 2004). An alternative interpretation of the mammals of the Split Rock Formation is that the fauna is late Hemingfordian to early Barstovian, suggesting that V69190 occurs in a reversed magnetozone that was instead correlated with chron $\mathrm{C} 5 \mathrm{Br}, 16.1-15.2$ Ma (Liter et al., 2008). Because there appears to be more evidence for a Hemingfordian fauna at V69190 with no Barstovian elements, I accept that UCMP 163737 is assigned a temporal range of 17.5-16.7 Ma, in agreement with a correlation of the magnetozone to chrons $\mathrm{C} 5 \mathrm{Dn}$ and $\mathrm{C} 5 \mathrm{Cr}$ instead of with chron $\mathrm{C} 5 \mathrm{Br}$. Date constraints using the combined evidence of paleomagnetic, radioisotopic, and biochronologic data provide valuable age information for fossils, but the chronostratigraphic age of V69190 remains open for refinement and revision with future improvements of faunal interpretations and new radioisotopic dates.

\section{OTHER MATERIAL}

UCMP 163012. The dentary (Figure 4) is referred to Lepidosauria and to Squamata on the basis of superficially attached and pleurodont teeth, respectively. An open, ventrally facing meckel's canal is apomorphic of Anguimorpha (Estes et al., 1988). Tooth crowns with a chisel-like appearance are present in Anguidae, as is a reduction of the angular process of the dentary, which results in a free margin of the intramandibular septum (Gauthier, 1982). A coronoid process that is distinct from the surangular process is present on the dentary in both Anguinae and Diploglossinae, but is absent in UCMP 163012. The specimen is diagnosable to Gerrhonotinae but does not possess any apomorphies of Elgaria. UCMP 163012 is also assigned a temporal range of 17.5-16.7 Ma.

\section{DISCUSSION}

The temporal range of Elgaria now extends at least as far back as the middle Miocene (17.5-16.7 Ma). The geographic range of Elgaria is extended into central Wyoming several hundred miles southeast of the nearest extant occurrence of the genus (Elgaria coerulea in central Idaho; Leavitt et al., 2017). This is consistent with previously reported non-apomorphic identifications of Elgaria from the Split Rock Formation of Wyoming during the middle Miocene (Robinson and Van Devender, 1973).

UCMP 163737 can be used for node calibrations. Phylogenetic analyses using molecular data recovered Elgaria as the sister taxon to other gerrhonotines and Elgaria coerulea as the sister taxon to other Elgaria (Conroy et al., 2005; Pyron et al., 2013; Zheng and Wiens, 2016; Leavitt et al., 2017; see Figure 1). Molecular clock analyses calibrated with fossil data (from Smith, 2009) recovered a split between Elgaria coerulea and other crown Elgaria at $15.2 \mathrm{Ma}$ (95\% confidence interval of 19.1-11.8 $\mathrm{Ma})$, but suggest a divergence time between stem Elgaria and other gerrhonotines of about $37 \mathrm{Ma}$ (95\% confidence interval of 45-31 Ma; Leavitt et al., 2017). UCMP 163737 occurred before the estimated split between Elgaria coerulea and other crown Elgaria, but within the $95 \%$ confidence inter- 
val of that split as recovered by Leavitt et al. (2017). Additional fossil material will further illuminate the evolutionary history of crown gerrhonotines during the Miocene.

The earliest known stem gerrhonotines appeared in the early Eocene (c. 54.8 Ma) and were found in the Bighorn Basin of Wyoming, approximately 200 miles north of the Granite Mountains (Smith, 2009; Leavitt et al., 2017). The new minimum age of 16.7 Ma for stem Elgaria and the basal split within crown Gerrhonotinae is later than the $37 \mathrm{Ma}$ divergence time of stem Elgaria recovered by molecular clock analysis and later than the 54.8 Ma age of the earliest known gerrhonotine fossils. Moreover, previous reports of gerrhonotines from Wyoming during the Late Cretaceous (Estes, 1964) suggest that the entire clade may have originated much earlier than the Eocene. The findings of the present study and the dearth of knowledge about early gerrhonotines open the door to many questions about the tempo- ral, geographic, and taxonomic origins of both stem and crown Gerrhonotinae.

\section{ACKNOWLEDGMENTS}

I thank P. Holroyd (UCMP), S. Graham (SRSU), and C. Sagebiel (TMM) for providing access to specimens. I thank M. Colbert and J. Maisano at UTCT for scanning specimens. B. Lander provided useful information on the Split Rock Formation. I thank D. Ledesma for his integral role in advancing the knowledge of gerrhonotine lizards. I thank $\mathrm{C}$. Bell for encouraging me to write this paper, for literature, and for comments on the manuscript. Funding was provided by the Geological Society of America, the Lundelius Grant for student research in Vertebrate Paleontology, and C. Bell. Reviews by two anonymous reviewers and D. Ksepka helped significantly improve the manuscript.

\section{REFERENCES}

Bhullar, B.A.S. 2011. The power and utility of morphological characters in systematics: A fully resolved phylogeny of Xenosaurus and its fossil relatives (Squamata: Anguimorpha). Bulletin of the Museum of Comparative Zoology, 160:65-181. https://doi.org/10.3099/0027-4100160.3.65

Conrad, J.L. 2008. Phylogeny and systematics of Squamata (Reptilia) based on morphology. Bulletin of the American Museum of Natural History, 310:1-182. https://doi.org/10.1206/310.1

Conrad, J.L., Ast, J.C., Montanari, S., and Norell, M.A. 2011. A combined evidence phylogenetic analysis of Anguimorpha. Cladistics, 27:230-277.

Conroy, C.J., Bryson Jr., R.W., Lazcano, D., and Knight, A. 2005. Phylogenetic placement of the pygmy alligator lizard based on mitochondrial DNA. Journal of Herpetology, 39:142-147.

Estes, R. 1963. A new gerrhonotine lizard from the Pliocene of California. Copeia, 1963:676680.

Estes, R. 1964. Fossil vertebrates from the late Cretaceous Lance Formation, eastern Wyoming. University of California Publications in Geological Sciences, 4:1-180.

Estes, R., De Queiroz, K., and Gauthier, J.A. 1988. Phylogenetic relationships within Squamata p. 119-281. In Estes, R. and Pregill, G.K. (eds.), Phylogenetic Relationships of the Lizard Families: Essays Commemorating Charles L. Camp. Stanford University Press, Stanford, California.

Estes, R. and Tihen, J.A. 1964. Lower vertebrates from the Valentine Formation of Nebraska. American Midland Naturalist, 72:453-472.

Evans, S.E. 2008. The skull of lizards and Tuatara, p. 1-347. In Gans, C., Gaunt, A.S., and Adler, K. (eds.), Biology of the Reptilia, Volume 20, Morphology H: The Skull of Lepidosauria. Society for the Study of Amphibians and Reptiles, Ithaca, New York.

Gauthier, J.A. 1982. Fossil xenosaurid and anguid lizards from the early Eocene Wasatch Formation, southeast Wyoming, and a revision of the Anguioidea. Contributions to Geology, University of Wyoming, 21:7-54.

Gauthier, J.A., Estes, R., and De Queiroz, K. 1988. A phylogenetic analysis of Lepidosauromorpha, p. 15-98. In Estes, R. and Pregill, G.K. (eds.), Phylogenetic Relationships of the Lizard Families: Essays Commemorating Charles L. Camp. Stanford University Press, Stanford, California. 
Gauthier, J.A., Kearney, M., Maisano, J.A., Rieppel, O., and Behlke A.D.B. 2012. Assembling the squamate tree of life: Perspectives from the phenotype and the fossil record. Bulletin of the Peabody Museum of Natural History, 53:3-308. https://doi.org/10.3374/014.053.0101

Gilmore, C.W. 1928. Fossil Lizards of North America. Memoirs of the National Academy of Sciences, 12:1-201.

Good, D.A. 1987. A phylogenetic analysis of cranial osteology in the gerrhonotine lizards. Journal of Herpetology, 21:285-297.

Good, D.A. 1988. The phylogenetic position of fossils assigned to the Gerrhonotinae (Squamata: Anguidae). Journal of Vertebrate Paleontology, 8:188-195.

Head, J.J. 2015. Fossil calibration dates for molecular phylogenetic analysis of snakes 1 : Serpentes, Alethinophidia, Boidae, Pythonidae. Palaeontologia Electronica, 18.1.6FC:1-17. https://doi.org/10.26879/487 palaeo-electronica.org/content/fc-6

Hilgen, F.J., Lourens, L.J., Van Dam, J.A., Beu, A.G., Boyes, A.F., Cooper, R.A., Krijgsman, W., Ogg, J.G., Piller, W.E., and Wilson, D.S. 2012. The Neogene Period, p. 923-978. In Gradstein, F.M. (ed.), The Geologic Time Scale 2012. Elsevier BV, Amsterdam, The Netherlands. https://doi.org/10.1016/B978-0-444-59425-9.00029-9

Holman, J.A. 1973. Reptiles of the Egelhoff Local Fauna (Upper Miocene) of Nebraska. Contributions from the Museum of Paleontology, The University of Michigan, 24:125-134.

Holman, J.A. 1976. The herpetofauna of the lower Valentine Formation, North-Central Nebraska. Herpetologica, 32:262-268.

Izett, G.A. and Obradovich, J.D. 2001. ${ }^{40} \mathrm{Ar} /{ }^{39} \mathrm{Ar}$ Ages of Miocene tuffs in basin-fill deposits (Santa Fe Group, New Mexico, and Troublesome Formation, Colorado) of the Rio Grande Rift System. The Mountain Geologist, 38:77-86.

Lamar, W.W., Barrio-Amorós, C.L., Dwyer, Q., Abarca, J.G., and De Plecker, R. 2015. The gerrhonotine genus Coloptychon (Sauria: Anguidae). Mesoamerican Herpetology, 2:88-104.

Lander, E.B., Santucci, V., and Tweet, J. 2013. 73rd Annual Meeting Field Trip Volume and Guidebook on Arikareean and Hemingfordian Mammalian Vertebrate Paleontology of the Santa Monica Mountains National Recreation Area, Los Angeles County, Southern California. Society of Vertebrate Paleontology, Bethesda, Maryland.

Leavitt, D.H., Marion, A.B., Hollingsworth, B.D., and Reeder, T.W. 2017. Multilocus phylogeny of alligator lizards (Elgaria, Anguidae): Testing mtDNA introgression as the source of discordant molecular phylogenetic hypotheses. Molecular Phylogenetics and Evolution, 110:104-121. https://doi.org/10.1016/j.ympev.2017.02.010

Liter, M.R., Prothero, D.R., and Hopkins, S.S.B. 2008. Magnetic stratigraphy of the late Hemingfordian-?Barstovian (lower to middle Miocene) Split Rock Formation, central Wyoming. New Mexico Museum of Natural History and Science Bulletin, 44:25-30.

Macey, J.R., Schulte, J.A., Larson, A., Tuniyev, B.S., Orlov, N., and Papenfuss, T.J. 1999. Molecular phylogenetics, tRNA evolution, and historical biogeography in anguid lizards and related taxonomic families. Molecular Phylogenetics and Evolution, 12:250-272.

Norell, M.A. 1989. Late Cenozoic lizards of the Anza Borrego Desert, California. Contributions in Science, Natural History Museum of Los Angeles County, 414:1-31.

Parham, J.F., Donoghue, P.C., Bell, C.J., Calway, T.D., Head, J.J., Holroyd, P.A., Inoue, J.G., Irmis, R.B., Joyce, W.G., Ksepka, D.T., Patane, J.S.L., Smith, N.D., Tarver, J.E., van Tuinen, M., Yang, Z., Angielczyk, K.D., Greenwood, J.M., Hipsley, C.A., Jacobs, L., Makovicky, P.J., Müller, J., Smith, K.T., Theodor, J.M., Warnock, R.C.M., and Benton, M.J. 2012. Best practices for justifying fossil calibrations. Systematic Biology, 61:346-359. https://doi.org/ 10.1093/sysbio/syr107

Pyron, R.A., Burbrink, F.T., Wiens, J.J. 2013. A phylogeny and revised classification of Squamata, including 4161 species of lizards and snakes. BMC Evolutionary Biology, 13:1-53. https://doi.org/10.1186/1471-2148-13-93

Robinson, M.D. and Van Devender, T.R. 1973. Miocene lizards from Wyoming and Nebraska. Copeia, 1973:698-704.

Smith, K.T. 2009. A new lizard assemblage from the earliest Eocene (Zone WA0) of the Bighorn Basin, Wyoming, USA: Biogeography during the warmest interval of the Cenozoic. Journal of Systematic Palaeontology, 7:299-358. https://doi.org/10.1017/S1477201909002752

Tedford, R.H., Alrbright, L.B.A., Barnosky, A.D., Ferrusquia-Villafranca, I., Hunt, R.M.J., Storer, J.E., Swisher, C.C., Voorhies, M.R., Webb, S.D., and Whistler, D.P. 2004. Mammalian biochronology of the Arikareean through Hemphillian interval (late Oligocene through early 
Pliocene epochs), p. 169-231. In: Woodburne, M.O. (ed.), Late Cretaceous and Cenozoic Mammals of North America: Biostratigraphy and Geochronology. Columbia University Press, New York.

Whistler, D.P. and Lander, E.B. 2003. New late Uintan to early Hemingfordian land mammal assemblages from the undifferentiated Sespe and Vaqueros formations, Orange County, and from the Sespe and equivalent marine formations in Los Angeles, Santa Barbara, and Ventura counties, Southern California. Bulletin of the American Museum of Natural History, 279:231-268. https://doi.org/10.1206/0003-0090(2003)279<0231:C>2.0.CO;2

Zheng, Y. and Wiens, J.J. 2016. Combining phylogenomic and supermatrix approaches, and a time-calibrated phylogeny for squamate reptiles (lizards and snakes) based on 52 genes and 4162 species. Molecular Phylogenetics and Evolution, 94:537-547. https://doi.org/10.1016/ j.ympev.2015.10.009 


\section{APPENDIX 1.}

\section{Specimens examined}

Anguis fragilis CAS 500, TMM M-8963; Anniella pulchra TMM M-8677, TMM M-9013; Diploglossus millepunctatus TMM M-9010; Diploglossus pleei CAS 200840; Elgaria coerulea CAS 14509, TMM M-8965; Elgaria kingii TMM M-8981; Elgaria multicarinata TMM M-8988; Gerrhonotus parvus SRSU 5537, SRSU 5538; Ophiodes striatus CAS 231485; Ophisaurus attenuatus TMM M8979; Ophisaurus ventralis CAS 74296, CAS 200896, TMM M-8585; Pseudopus apodus TMM M-9002; Xenosaurus grandis TMM M-8960. 